\title{
The Relationship between Scientific Inquiry and Communication Skills with Beliefs about the Nature of Science of Pre-Service Science Teachers'
}

\author{
Nilgün Yenice \\ Faculty of Education, Aydın Adnan Menderes University, Aydın, Turkey \\ ORCID: 0000-0002-7935-3110
}

Barış Özden*

Ministry of National Education, Afyonkarahisar, Turkey

ORCID: 0000-0002-2049-6766

Article history

Received:

13.03.2021

Received in revised form: 08.06.2021

Accepted:

11.06.2021

Key words:

Nature of science,

Communication,

Pre-service science teachers,

Scientific inquiry,

Science learning skills.
The aim of the study was to determine the correlations between preservice science teachers' beliefs about the nature of science and their scientific inquiry and communication skills. The study group of the research was composed of 329 pre-service science teachers who are studying at Aydın Adnan Menderes and Muğla Universities of Turkey during the academic year of 2018-2019. The data were obtained by using "Beliefs about the Nature of Science Scale" and "Skills Learning Science Scale". In addition to descriptive statistics, independent samples t test, one-way analysis of variance and stepwise multiple regression analyses were used in the analysis of the data. The result of the study indicated that pre-service science teachers had nearly "Acceptable" beliefs about the nature of science. Their scientific inquiry and communication skills were found to be nearly "High". In this study, it was concluded that imagination and creativity, assumptions and boundaries of science and observation and inference, explained approximately $12 \%$ of the variance in scientific inquiry skills. In addition, it was concluded that assumptions and boundaries of science, imagination and creativity and observation and inference, explained approximately $13 \%$ of the variance in communication skills. In light of the findings, suggestions were presented at the end of the study.

\section{Introduction}

Today one of the major goals for science education has been stated as producing science literate individuals (Abd-El-Khalick \& Lederman, 2000). According to the National Science Education Standards (National Research Center [NRC], 1996), scientific literacy is defined as, "the knowledge and understanding of scientific concepts and processes required for personal decision making, participation in civic and cultural affairs, and economic productivity" (Roberts, 2008: 22). In line with this definition, science literacy is one of the most important concepts among $21^{\text {st }}$ century skills and its basic components are "field

\footnotetext{
*Correspondency: barisozdn@gmail.com
} 
knowledge", "nature of science" and "scientific inquiry" (Lederman, 2009). Therefore, it is of great importance to teach the scientific inquiry process and to gain an understanding of the nature of science in science education. At the same time, in the definition of scientific literacy within the framework of biology and science education, the focus is on the understanding of the nature of scientific knowledge and the process of scientific inquiry (Lederman, Lederman \& Antink, 2013; Roberts, 20078; Schwartz \& Crawford, 2003).

One of the messages behind the reforms in science education is "to improve students" understanding about the nature of science" (The American Association for the Advancement of Science [AAAS], 1993; National Research Center [NRC], 1996; 2000). There are many varied definitions of the nature of science though. For instance, it is defined as "The values and hypothesis in the nature of science and scientific knowledge and the development of scientific knowledge" (Lederman, 1992: 331). In another definition, it is stated that the nature of science includes the characteristics of scientific knowledge and scientists, reading scientific publications, participating in scientific discussions, the way through which science affects society and how it is affected by society (Driver, Leach, Millar, \& Scott, 1996). Despite the different definitions of the nature of science in the literature; researchers who work in this field have reached a consensus on the characteristics of the nature of science (Lederman, Abd-El-Khalick, Bell \& Schwartz, 2002; Lederman, 2007; McComas, Clough \& Almazroa, 2000). These characteristics can be expressed as follows: "Changeability of Scientific Knowledge, Distinctions between Observation and Inference, Scientific Method/Methodology, Creativity and Imagination, Socio-Cultural Effects and Scientific Theories and Law".

Although scientific inquiry has become a part of educational programs in recent times, it has been regarded as one of the important parts of education for decades (AAAS, 1993; NCR, 1996, 2000; MoNE, 2013). As a matter of fact, scientific inquiry refers to the use of scientific process skills including data analysis, hypothesis formation, and interpretation to construct scientific knowledge (Klahr \& Dunbar, 1988; Lederman et al., 2002; Roberts \& Gott, 1999). Similarly, scientific inquiry refers to the combination of general science process skills with traditional science content, creativity, and critical thinking to develop scientific knowledge (Lederman, 2009). the meaning of scientific inquiry and its components have been a point of discussion for a long time. By examining the components of scientific inquiry in the literature, eight components that are compatible with the science education context from pre-school to undergraduate level have been brought together (Crawford, 2014; Lederman et al., 2014; Schwartz, Lederman \& Lederman, 2004). These components are given below:

- Scientific investigations all begin with a question, but do not necessarily test a hypothesis.

- There is no single set or sequence of steps followed in all investigations.

- Inquiry procedures are guided by the questions asked.

- All scientists performing the same procedures may not get the same results.

- Inquiry procedures can influence the results.

- Research conclusions must be consistent with the data collected.

- Scientific data are not the same as evidence.

- Explanations are developed from a combination of collected data and what is already known.

Two important aspects that contribute to the notion of scientific literacy are nature of science and scientific inquiry. The concepts of scientific inquiry and nature of science are often used interchangeably (Lederman, 2007; Lederman et al., 2014). However, according to 
Lederman (2007), scientific inquiry is closely related to the nature of science; but it is not the same as it. Because scientific inquiry includes asking questions, planning and applying the research, mathematical thinking, analyzing and interpreting data, and using communication skills effectively in explaining the facts with evidence in the part of sharing and discussing the findings (NRC, 2012; Pedaste et al., 2015). On the other hand, nature of science refers to certain characteristics that limit and do not limit the use of scientific knowledge produced as a result of scientific inquiry. Therefore, it can be said that scientific inquiry and the nature of science are different concepts.

When the science curriculum is examined, it is emphasized that students should acquire communication skills as well as developing beliefs in the nature of science and gaining scientific inquiry skills (MoNE, 2018). Because it is among the characteristics of the science literate individual that sharing the knowledge and skills acquired through science courses with those around. It is known that communication is an inseparable part of scientific activities and can be seen as a basis for scientific knowledge. At the same time, communication is one of the basic elements of the nature of science (Nielsen, 2012). Therefore, those students with higher level beliefs about the nature of science and higher levels of scientific inquiry have higher levels of communication skills. Communication can be considered as an effort to ensure that qualities such as information, thoughts, and behavior are shared among individuals or groups (Güven, 2013). Communication skills include sensitivity to verbal and non-verbal messages, listening effectively and responding effectively (Korkut, 2005). Communication skills cover an ability to communicate verbally or in written form, but they also cover the efficient use of mathematical symbols, graphics, tables and figures in communicating the findings of the study. Therefore, students who have a good command of communication skills should make use of varied forms to transfer their information to others (Şenler, 2014).

There are numerous studies dealing with the nature of science from the perspectives of students, pre-service teachers and teachers (Adedoyin \& Bello, 2017; Colagrande, Martorano \& Arroio, 2016; Çakmak, 2017; Kesgin, 2019; Korkmaz, 2018; Öztaş, 2019; Saif, 2016; Shaakumani \& Csapo, 2019; Yenice, Özden \& Balc1, 2015). There are also studies concerning scientific inquiry and communication skills. Some of them are focused on inquiry based teaching (Kara, 2019; Ordu, 2019) or on inquiry skills and questions (types or frequency) used in class (Şahin, 2007). On the other hand, inquiry skills of pre-service teachers have been relatively less studied (Baykara, Yakar \& Liu, 2018; Bostan-Saroğlan, 2018; Haefner \& Zembal-Saul, 2004; Şenler, 2017). Baykara, Yakar and Liu (2018) aimed to determine the opinions of pre-service science teachers towards scientific inquiry in their study. Haefner and Zembal-Saul (2004) aimed to examine prospective elementary teachers' learning about scientific inquiry in the context of an innovative life science course. Bostan Saroğlan (2018) aimed to investigate the opinion of pre-service science teachers about scientific inquiry after making them being exposed to certain instruction in his research. Although there are studies dealing with the beliefs about the nature of science and scientific inquiry (Aydemir, Uğraş, Cambay \& Kılıç, 2017; Ayyılmaz Çelik, 2019; Kremer, Specht, Urhahne \& Mayer, 2013; Stott \& Hattingh, 2020) and with communication skills (Yaman, 2020; Milli \& Yağc1, 2017; Nielsen, 2012; Saracaloğlu, Yenice \& Karasakaloğlu, 2009), the interactions between the beliefs about the nature of science and the skills of scientific inquiry and communication have been less studied. Moreover, there is a limited number of studies in the field, in which the beliefs about the nature of science, scientific inquiry and communication skills of pre-service science teachers' are investigated according to the variables of grade and grade level. 
Science teachers play an important role in students becoming scientific literacy individuals. As argued by Çepni, Ayvacı and Bacanak (2006) students' beliefs about the nature of science could be improved by those teachers who have refined beliefs about it. Given that the beliefs about the nature of science and the skills of scientific inquiry and communication are closely related, the levels of beliefs and skills mentioned above should be identified in pre-service science teachers. In this way, an important infrastructure can also be created for applications that can be developed to transform unearned or insufficiently acquired skills. In addition, it can be thought that this study will contribute to the literature, due to the limited number of studies investigating the relationship of variables mentioned in the literature.

The aim of the study is then to determine the correlations between pre-service science teachers' beliefs about the nature of science and their scientific inquiry and communication skills. For this purpose, answers were sought for the following sub-problems:

(1) What is the level of the pre-service science teachers' beliefs about the nature of science?

(2) What is the level of the pre-service science teachers' scientific inquiry and communication skills?

(3) Do pre-service science teachers' beliefs on the nature of science differ significantly according to the variables of gender and grade level?

(4) Do pre-service science teachers' scientific inquiry and communication skills differ significantly according to the variables of gender and grade level?

(5) Do pre-service science teachers' beliefs about the nature of science significantly predict their scientific inquiry and communication skills?

\section{METHOD}

\section{Research Model}

Correlational survey research, one of the general scanning methods, was used in the research.

\section{Participants}

The participants were 329 Pre-Service Science Teachers (PSTs) attending Aydin Adnan Menderes University and Muğla University in Turkey during the academic year of 2018-2019. They were selected following the convenient sampling technique. Creswell (2008) defined convenience sampling as the one when researchers selected participants because they were willing and readily available. Table 1 shows the demographical characteristics of the participants.

Table 1. Demographical characteristics of the participants

\begin{tabular}{lll}
\hline Gender & $\mathbf{N}$ & $\mathbf{\%}$ \\
\hline Female & 252 & 76.6 \\
\hline Male & 77 & 23.4 \\
\hline Total & 329 & 100 \\
\hline Grade level & $\mathbf{N}$ & $\mathbf{\%}$ \\
\hline $1^{\text {st }}$ Grade & 78 & 23.7 \\
\hline $2^{\text {nd }}$ Grade & 103 & 31.3 \\
\hline $3^{\text {rd }}$ Grade & 86 & 26.1 \\
\hline
\end{tabular}




\begin{tabular}{lll}
\hline $4^{\text {th }}$ Grade & 62 & 18.8 \\
\hline Total & 329 & 100 \\
\hline
\end{tabular}

\section{Data Collection Tools}

\section{Beliefs about the Nature of Science Scale}

This scale developed by Özcan and Turgut (2014), was used to reveal the levels of participants' beliefs about the nature of science. The scale is made up of 37 items. These are answered with a 5-point likert type scale: (5) Totally Agree, (4) Agree, (3) Undecided, (2) Disagree and (1) Totally Disagree. The opposite statements were scored in reverse order. The maximum score from the scale was " 185 " and the minimum score was " 37 ". The scale has seven dimensions. Each dimension focuses on one variable. These dimensions are named as follows: "Change of Scientific Knowledge", "Observation and Inference", "Scientific Method/Methodology", "Imagination and Creativity", "Assumptions and Boundaries of Science", "Socio-Cultural Effect" and "Scientific Theories and Laws". While six of the dimensions of this scale focused on variables that were common in the related literature, an important contribution has been made to the measurement process with the seventh subdimension called "Assumptions and Boundaries of Science" pertinent to epistemological thinking and beliefs. In the present study, the results of confirmatory factor analysis showed a good fit $\left(\chi^{2} / \mathrm{df}=2.65, \mathrm{RMSEA}=.08, \mathrm{PGFI}=.65, \mathrm{PNFI}=.70\right)$ based on the assessment criteria $\chi^{2} /$ df below 5 (Wheaton et al., 1977), PGFI and PNFI above .50 (Meyers, Gamst \& Guarino, 2006), RMSEA below .08. Thus, the factor structure of the scale fits the data well. As a result of the reliability analysis conducted by the researchers who developed the scale, Cronbach Alpha reliability coefficient was found to be .78 for the whole scale. In addition, as a result of the reliability analysis for this study, the Cronbach Alpha internal consistency coefficient was between .60 and. 70 for the sub-dimensions; it was determined as .70 for all of them. Because of the disadvantages of likert type measurement tools, the use of measurement tools consisting of open-ended questions is recommended. However, it is stated that these tools have the disadvantages such as the difficulty in providing the standard in measurement and the limited number of them. On the other hand, scales are easier to use than other measurement tools and have usefulness, saving time and money for the researcher and allowing objectivity in evaluation. Therefore, it is decided to use likert type scale in order to determine the beliefs about the nature of science. Examples of items included in the scale were presented below:

- If information is scientific, it has been proven precisely and it will not change anymore.

- If different scientists have the same data, they will reach the same result.

- Supernatural beings like angels and giants cannot be the subject of examination of science.

\section{Skills Learning Science Scale}

This scale developed by Chang et al., (2011) was used to identify the level of preservice science teachers' scientific inquiry and communication skills. The scale was adapted into Turkish by Şenler (2014). The original scale was made up of two dimensions, scientific inquiry and communication. Each dimension had four sub-dimensions. The scientific inquiry subscale consists of "proposing questions and hypotheses", "planning", "experimenting and collecting data" and "analyzing data, interpreting and reaching conclusions" sub-dimensions. 
The communication subscale includes "expressing", "evaluating", "interacting" and "negotiating" sub-dimensions. The scale is consisted of 29 items, which are answered on a 5point likert type scale: (5) Totally Agree (4) Agree, (3) Undecided, (2) Disagree and (1) Totally Disagree. Higher scores reflect higher levels of skills. In the present study, the results of confirmatory factor analysis showed a good fit $\left(\chi^{2} / \mathrm{df}=3.53\right.$, RMSEA $=.08$, PGFI $=.67$, PNFI $=.71$ ) based on the assessment criteria $\chi^{2} / \mathrm{df}$ below 5 , (Wheaton et al., 1977), PGFI and PNFI above .50 (Meyers, Gamst \& Guarino, 2006), RMSEA below .08. Thus, the factor structure of the scale fits the data well. As a result of the reliability analysis conducted by the researchers who developed the scale, Cronbach Alpha reliability coefficient was found to be .93 for the whole scale. In addition, as a result of the reliability analysis for this study, the Cronbach Alpha internal consistency coefficient was determined between .88 and.89 for the subscales. Cronbach Alpha internal consistency coefficient was determined as .95 for the whole scale. Examples of items included in the scale were presented below:

- I can use experimental materials to collect data.

- I can show relationships between data through graphs or mathematical symbols.

- I can ask questions about my classmates' incomprehensible expressions.

- I can share my ideas with my classmates through discussion.

\section{Data Analysis}

The data obtained were analyzed with SPSS 20.0 (Statistical Package for Social Science). For independent samples using the t-test and one way variance analysis requires that the scores for dependent variables should normally distribute and variances should be homogenous (Büyüköztürk, 2011). For this reason, the Kolmogorov-Smirnov normality test was conducted for the nature of science belief scale scores and scientific inquiry and communication skill scores. As a result of the analysis, it was determined that the obtained scores did not meet the normality assumption $(\mathrm{p}<.05)$. However, when the distribution charts, skewness and kurtosis values of the data were examined, it was seen that the skewness and kurtosis values of the data were in the range of $+1.0 /-1.0$. A kurtosis value between \pm 1.0 is considered excellent for most psychometric purposes, but a value between \pm 2.0 is in many cases also acceptable, depending on the particular application (George \& Mallery, 2012). Skewness values falling outside the range of -1 to +1 indicate a substantially skewed distribution (Hair, Black, Babin \& Anderson, 2010). In this context, assuming that the data is distributed normally, in addition to descriptive statistics, independent samples for t test, oneway analysis of variance and stepwise multiple regression analysis were used in the analysis of the data. As a result of the process of removing the extreme values before the analysis of the research data, the data of four students were not included in the analysis, and the analyses were carried out on 325 students.

\section{RESULTS}

\section{Results Related to First Sub-Problem}

In order to answer the first sub-problem which is: "What is the level of the pre-service science teachers' beliefs about the nature of science?, the descriptive statistics is used and the results, such as arithmetical mean, standard deviation, maximum and minimum values are given in Table 2. 
Table 2. Descriptive statistics of the pre-service science teachers' scores

\begin{tabular}{|c|c|c|c|c|c|c|}
\hline Scale & Dimension & $\mathbf{N}$ & Mean & SD & Min & Max \\
\hline \multirow{7}{*}{ 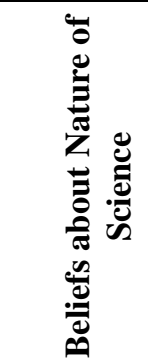 } & Change of Scientific Knowledge & 325 & 3.51 & .55 & 2.00 & 5.00 \\
\hline & Observation and Inference & 325 & 3.33 & .57 & 2.00 & 5.00 \\
\hline & Scientific Method/Methodology & 325 & 2.97 & .56 & 1.50 & 4.75 \\
\hline & Imagination and Creativity & 325 & 3.60 & .58 & 1.80 & 5.00 \\
\hline & Assumptions and Boundaries of & 325 & 3.48 & .41 & 2.38 & 4.88 \\
\hline & Socio-Cultural Effect & 325 & 3.18 & .74 & 1.00 & 5.00 \\
\hline & Scientific Theories and Laws & 325 & 3.07 & .36 & 1.83 & 4.17 \\
\hline & Total & 325 & 3.31 & .30 & 2.56 & 4.52 \\
\hline
\end{tabular}

As can be seen in Table 2 the mean score on scale for the beliefs about the nature of science was found to be 3.31 with the standard deviation of .30 . The highest mean score on scale for the beliefs about the nature of science is 4.52 and the lowest mean score on the scale is 2.56 . Among the dimensions of the scale the one with the highest mean score was found to be "Imagination and Creativity" with the mean score of 3.60. It is "Scientific Method/Methodology" which had the lowest mean score, 2.97. Given that the mean score for the scale for the beliefs about the nature of science is higher than the median score $(M=3.00)$, it can be stated that the pre-service science teachers participated in the study have nearly "Acceptable" beliefs about the nature of science except for the subdimension of "scientific method/methodology".

\section{Results Related to Second Sub-Problem}

In order to answer the second sub-problem, the descriptive statistics is used and the results, such as arithmetical mean, standard deviation, maximum and minimum values are given in Table 3.

Table 3. Descriptive statistics of the pre-service science teachers' scores

\begin{tabular}{|c|c|c|c|c|c|c|}
\hline Sub-scale & Dimension & $\mathbf{N}$ & Mean & SD & Min & $\operatorname{Max}$ \\
\hline \multirow{4}{*}{ 总 } & Proposing Questions and Hypotheses & 325 & 4.15 & .56 & 2.00 & 5.00 \\
\hline & Planning & 325 & 3.97 & .61 & 2.00 & 5.00 \\
\hline & Experimenting and Collecting Data & 325 & 4.10 & .63 & 1.67 & 5.00 \\
\hline & $\begin{array}{l}\text { Analyzing Data, Interpreting and } \\
\text { Reaching Conclusions }\end{array}$ & 325 & 4.01 & 60 & 2.25 & 5.00 \\
\hline \multicolumn{2}{|r|}{ Total } & 325 & 4,05 & .51 & 2.36 & 5.00 \\
\hline \multirow{4}{*}{ 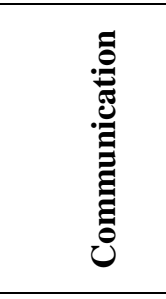 } & Expressing & 325 & 3.87 & .66 & 1.75 & 5,00 \\
\hline & Evaluating & 325 & 3.97 & .58 & 2.00 & 5.00 \\
\hline & Interacting & 325 & 4.01 & .65 & 2.00 & 5.00 \\
\hline & Negotiating & 325 & 4.05 & .64 & 1.50 & 5.00 \\
\hline \multicolumn{2}{|r|}{ Total } & 325 & 3.98 & .53 & 2.40 & 5.00 \\
\hline
\end{tabular}

As can be seen in Table 3 the mean score on scale for the scientific inquiry skills was found to be 4.05 with the standard deviation of .51 . The highest mean score on the scale for the scientific inquiry skills is 5.00 and the lowest mean score on the scale is 2.36. Among the dimensions of the scale the one with the highest mean score was found to be "Proposing Questions and Hypotheses" with the mean score of 4.15. It is "Planning" which had the 
lowest mean score, 3.97 .

The mean score on the scale for the communication skills was found to be 3.98 with the standard deviation of .53. The highest mean score on the scale for the communication skills is 5.00 and the lowest mean score on the scale is 2.40. Among the dimensions of the scale the one with the highest mean score was found to be "Negotiating" with the mean score of 4.05. It is "Expressing" which had the lowest mean score, 3.87. Given that the total mean score for the scale for the scientific inquiry and communication skills is higher than the median score $(\mathrm{M}=3.00)$, it can be said that the scientific inquiry and communication skills of the science teacher candidates are close to the "High" level.

\section{Results Related to Third Sub-Problem}

The findings about the third sub-problem of the research are given below.

\section{Effects of gender on the beliefs about the nature of science}

In order to see if gender has any significant effects on the beliefs about the nature of science of the pre-service science teachers participated in the study the Independent Samples for t-test was employed. The results of the test are given in Table 4.

Table 4. The results of the Independent Samples for t-test concerning pre-service science teachers' scores

\begin{tabular}{|c|c|c|c|c|c|c|c|c|}
\hline & Dimension & Gender & $\mathbf{N}$ & $\mathbf{X}$ & SD & df & $\mathbf{t}$ & $P$ \\
\hline \multirow{14}{*}{ 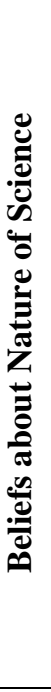 } & \multirow{2}{*}{$\begin{array}{l}\text { Change of } \\
\text { Knowledge }\end{array}$} & Female & 251 & 3.50 & .54 & \multirow{2}{*}{323} & \multirow{2}{*}{-.339} & \multirow{2}{*}{.735} \\
\hline & & Male & 74 & 3.53 & .55 & & & \\
\hline & \multirow{2}{*}{ Observation and Inference } & Female & 251 & 3.35 & .55 & \multirow{2}{*}{323} & \multirow{2}{*}{.971} & \multirow{2}{*}{.333} \\
\hline & & Male & 74 & 3.27 & .60 & & & \\
\hline & \multirow{2}{*}{$\begin{array}{l}\text { Scientific } \\
\text { Method/Methodology }\end{array}$} & Female & 251 & 2.95 & .55 & \multirow{2}{*}{323} & \multirow{2}{*}{-1.175} & \multirow{2}{*}{.243} \\
\hline & & Male & 74 & 3.04 & .50 & & & \\
\hline & \multirow{2}{*}{ Imagination and Creativity } & Female & 251 & 3.61 & .57 & \multirow{2}{*}{323} & \multirow{2}{*}{.545} & \multirow{2}{*}{.587} \\
\hline & & Male & 74 & 3.57 & .63 & & & \\
\hline & \multirow{2}{*}{$\begin{array}{l}\text { Assumptions and } \\
\text { Boundaries of Science }\end{array}$} & Female & 251 & 3.47 & .40 & \multirow{2}{*}{323} & \multirow{2}{*}{-.723} & \multirow{2}{*}{.471} \\
\hline & & Male & 74 & 3.52 & .45 & & & \\
\hline & \multirow{2}{*}{ Socio-Cultural Effect } & Female & 251 & 3.18 & .74 & \multirow{2}{*}{323} & \multirow{2}{*}{.275} & \multirow{2}{*}{.784} \\
\hline & & Male & 74 & 3.16 & .73 & & & \\
\hline & \multirow{2}{*}{$\begin{array}{l}\text { Scientific } \\
\text { Laws }\end{array}$} & Female & 251 & 3.10 & .33 & \multirow{2}{*}{323} & \multirow{2}{*}{1.727} & \multirow{2}{*}{$.049 *$} \\
\hline & & Male & 74 & 3.00 & .43 & & & \\
\hline & \multirow{2}{*}{ Total } & Female & 252 & 3.31 & .29 & \multirow{2}{*}{323} & \multirow{2}{*}{.323} & \multirow{2}{*}{.776} \\
\hline & & Male & 77 & 3.30 & .31 & & & \\
\hline
\end{tabular}

$* \mathrm{p}<.05$

Table 4 indicates that gender does not have any significant effects on the pre-service science teachers' beliefs about the nature of science except for the subdimension of "Scientific Theories and Laws" ( $p>$.05). The gender-induced difference in the dimension of "Scientific Theories and Laws" was in favor of female pre-service science teachers' $(p<.05)$. 
Effects of the grade level on the beliefs about the nature of science

In order to see if grade level of the pre-service science teachers has any significant effects on the beliefs about the nature of science of the pre-service science teachers participated in the study the One-Way Analysis of Variance was employed. The results of the analysis are given in Table 5.

Table 5. The results of the One-Way Analysis of Variance concerning pre-service science teachers' scores

\begin{tabular}{|c|c|c|c|c|c|c|c|c|c|}
\hline Scale & Dimension & $\begin{array}{l}\text { Grade } \\
\text { Level }\end{array}$ & $\mathbf{N}$ & $\mathbf{X}$ & SD & df & $\mathbf{F}$ & $\mathbf{p}$ & $\begin{array}{l}\text { Significant } \\
\text { Difference }\end{array}$ \\
\hline \multirow{28}{*}{ 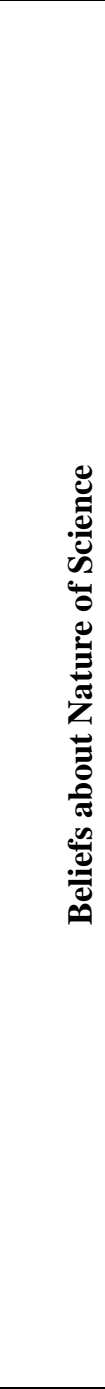 } & \multirow{4}{*}{$\begin{array}{l}\text { Change } \\
\text { Scientific } \\
\text { Knowledge }\end{array}$} & $1^{\mathrm{st}}$ & 77 & 3.40 & .50 & \multirow{4}{*}{3} & \multirow{4}{*}{14.541} & \multirow{4}{*}{$.000 *$} & \multirow{4}{*}{$1-3.2-3,2-4$} \\
\hline & & $2^{\text {nd }}$ & 101 & 3.31 & .49 & & & & \\
\hline & & $3^{\mathrm{rd}}$ & 85 & 3.78 & .49 & & & & \\
\hline & & $4^{\text {th }}$ & 62 & 3.58 & .57 & & & & \\
\hline & \multirow{4}{*}{$\begin{array}{l}\text { Observation } \\
\text { and Inference }\end{array}$} & $1^{\text {st }}$ & 77 & 3.27 & .47 & \multirow{4}{*}{3} & \multirow{4}{*}{5.415} & \multirow{4}{*}{$.001 *$} & \multirow{4}{*}{$2-3,2-4$} \\
\hline & & $2^{\text {nd }}$ & 101 & 3.18 & .44 & & & & \\
\hline & & $3^{\text {rd }}$ & 85 & 3.47 & .66 & & & & \\
\hline & & $4^{\text {th }}$ & 62 & 3.44 & .64 & & & & \\
\hline & \multirow{4}{*}{$\begin{array}{l}\text { Scientific } \\
\text { Method/Metho } \\
\text { dology }\end{array}$} & $1^{\mathrm{st}}$ & 77 & 2.91 & .48 & \multirow{4}{*}{3} & \multirow{4}{*}{1.660} & \multirow{4}{*}{.176} & \multirow{4}{*}{ - } \\
\hline & & $2^{\text {nd }}$ & 101 & 2.90 & .54 & & & & \\
\hline & & $3^{\text {rd }}$ & 85 & 3.04 & .57 & & & & \\
\hline & & $4^{\text {th }}$ & 62 & 3.05 & .64 & & & & \\
\hline & \multirow{4}{*}{$\begin{array}{l}\text { Imagination } \\
\text { and Creativity }\end{array}$} & $1^{\text {st }}$ & 77 & 3.28 & .62 & \multirow{4}{*}{3} & \multirow{4}{*}{23.842} & \multirow{4}{*}{$.000 *$} & \multirow{4}{*}{$\begin{array}{l}1-3,1-4 \\
2-3,2-4\end{array}$} \\
\hline & & $2^{\text {nd }}$ & 101 & 3.48 & .43 & & & & \\
\hline & & $3^{\text {rd }}$ & 85 & 3.93 & .51 & & & & \\
\hline & & $4^{\text {th }}$ & 62 & 3.74 & .56 & & & & \\
\hline & \multirow{4}{*}{$\begin{array}{l}\text { Assumptions } \\
\text { and } \\
\text { Boundaries of } \\
\text { Science }\end{array}$} & $1^{\text {st }}$ & 77 & 3.36 & .37 & \multirow{4}{*}{3} & \multirow{4}{*}{8.359} & \multirow{4}{*}{$.000 *$} & \multirow{4}{*}{$1-3,2-3$} \\
\hline & & $2^{\text {nd }}$ & 101 & 3.40 & .37 & & & & \\
\hline & & $3^{\mathrm{rd}}$ & 85 & 3.64 & .46 & & & & \\
\hline & & $4^{\text {th }}$ & 62 & 3.52 & .35 & & & & \\
\hline & \multirow{4}{*}{$\begin{array}{l}\text { Socio-Cultural } \\
\text { Effect }\end{array}$} & $1^{\text {st }}$ & 77 & 2.95 & .74 & \multirow{4}{*}{3} & & & \\
\hline & & $2^{\text {nd }}$ & 103 & 2.91 & .65 & & 17440 & $000 *$ & $1-3,1-4$ \\
\hline & & $3^{\text {rd }}$ & 86 & 3.57 & .69 & & 17.440 & .000 & $2-3,2-4$ \\
\hline & & $4^{\text {th }}$ & 62 & 3.32 & .67 & & & & \\
\hline & & $1^{\mathrm{st}}$ & 77 & 3.04 & .33 & & & & \\
\hline & Scientific & $2^{\text {nd }}$ & 101 & 3.01 & .28 & 2 & 2076 & $022 *$ & 23 \\
\hline & $\begin{array}{l}\text { Theories and } \\
\text { Laws }\end{array}$ & $3^{\text {rd }}$ & 85 & 3.17 & .39 & 3 & $2.9 / 6$ & $.032^{*}$ & $2-3$ \\
\hline & & $4^{\text {th }}$ & 62 & 3.06 & .43 & & & & \\
\hline & & $1^{\text {st }}$ & 77 & 3.17 & .22 & & & & \\
\hline & $T$ Tot & $2^{\text {nd }}$ & 101 & 3.17 & .20 & 2 & 24041 & O०O* & $1-3,1-4$ \\
\hline & I otal & $3^{\text {rd }}$ & 85 & 3.51 & .30 & 3 & 34.841 & $.000^{2}$ & $2-3,2-4$ \\
\hline & & $4^{\text {th }}$ & 62 & 3.39 & .33 & & & & \\
\hline
\end{tabular}

$* \mathrm{p}<.05$

As can be seen in Table 5 the grade level has significant effects on the pre-service science teachers' beliefs about the nature of science except for the subdimension of "scientific method/methodology" ( $p<.05)$. All significant differences are in favor of those pre-service 
science teachers, who were attending higher grades. Therefore, it can be said that the nature of science beliefs of pre-service teachers with a high grade level, except for the "scientific method/methodology" sub-dimension, are at a more acceptable level than those with a lower grade level. Moreover, it was determined that $3^{\text {rd }}$ grade pre-service teachers had higher beliefs about the nature of science than $4^{\text {th }}$ grade pre-service teachers.

\section{Results Related to Fourth Sub-Problem}

The findings about the fourth sub-problem of the research are given below.

\section{Effects of gender on the scientific inquiry and communication skills}

In order to see if gender has any significant effects on the scientific inquiry and communication skills of the pre-service science teachers participated in the study the Independent Samples for t-test was employed. The results of the test are given in Table 6.

Table 6. The results of the Independent Samples for t-test concerning pre-service science teachers' scores

\begin{tabular}{|c|c|c|c|c|c|c|c|c|}
\hline & Dimension & Gender & $\mathbf{N}$ & $\mathbf{X}$ & SD & df & $\mathbf{t}$ & $p$ \\
\hline \multirow{10}{*}{ 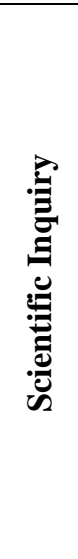 } & \multirow{2}{*}{$\begin{array}{l}\text { Proposing Questions and } \\
\text { Hypotheses }\end{array}$} & Female & 251 & 4.18 & .52 & \multirow{2}{*}{323} & \multirow{2}{*}{1.609} & \multirow{2}{*}{.111} \\
\hline & & Male & 74 & 4.04 & .66 & & & \\
\hline & \multirow{2}{*}{ Planning } & Female & 251 & 3.97 & .60 & \multirow{2}{*}{323} & \multirow{2}{*}{.169} & \multirow{2}{*}{.886} \\
\hline & & Male & 74 & 3.95 & .61 & & & \\
\hline & \multirow{2}{*}{$\begin{array}{l}\text { Experimenting } \\
\text { Collecting Data }\end{array}$} & Female & 251 & 4.13 & .60 & \multirow{2}{*}{323} & \multirow{2}{*}{1.242} & \multirow{2}{*}{.217} \\
\hline & & Male & 74 & 4.01 & .71 & & & \\
\hline & \multirow{2}{*}{$\begin{array}{l}\text { Analyzing } \quad \text { Data, } \\
\text { Interpreting and Reaching } \\
\text { Conclusions }\end{array}$} & Female & 251 & 4.03 & .57 & \multirow{2}{*}{323} & \multirow{2}{*}{1.174} & \multirow{2}{*}{.243} \\
\hline & & Male & 74 & 3.93 & .67 & & & \\
\hline & \multirow{2}{*}{ Total } & Female & 251 & 4.06 & .49 & \multirow{2}{*}{323} & \multirow{2}{*}{1.169} & \multirow{2}{*}{.245} \\
\hline & & Male & 74 & 3.98 & .57 & & & \\
\hline \multirow{8}{*}{ 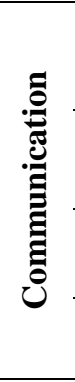 } & \multirow{2}{*}{ Expressing } & Female & 251 & 3.98 & .62 & \multirow{2}{*}{323} & \multirow{2}{*}{.762} & \multirow{2}{*}{.447} \\
\hline & & Male & 74 & 3.82 & .79 & & & \\
\hline & \multirow{2}{*}{ Evaluating } & Female & 251 & 3.98 & .58 & \multirow{2}{*}{323} & \multirow{2}{*}{.301} & \multirow{2}{*}{.764} \\
\hline & & Male & 74 & 3.95 & .60 & & & \\
\hline & \multirow{2}{*}{ Interacting } & Female & 251 & 4.05 & .61 & \multirow{2}{*}{323} & \multirow{2}{*}{1.791} & \multirow{2}{*}{.074} \\
\hline & & Male & 74 & 3.89 & .75 & & & \\
\hline & Negotiating & Female & 251 & 4.07 & .60 & 323 & 1144 & 254 \\
\hline & Negotiatıng & Male & 74 & 3.97 & .78 & 323 & 1.144 & .254 \\
\hline & Total & Female & 252 & 3.99 & .49 & 323 & 1163 & 246 \\
\hline & lotal & Male & 77 & 3.91 & .62 & 325 & 1.163 & .246 \\
\hline
\end{tabular}

Table 6 indicates that gender does not have any significant effects on the pre-service science teachers' scientific inquiry and communication skills $(p>.05)$. In addition, it was determined that female pre-service teachers' scientific inquiry and communication skills mean scores were higher than those of male pre-service teachers.

\section{Effects of the grade level on the scientific inquiry and communication skills}

In order to see if grade level of the pre-service science teachers has any significant effects on the scientific inquiry and communication skills of the pre-service science teachers 
participated in the study the One-Way Analysis of Variance was employed. The results of the analysis are given in Table 7.

Table 7. The results of the One-Way Analysis of Variance concerning pre-service science teachers' scores

\begin{tabular}{|c|c|c|c|c|c|c|c|c|c|}
\hline $\begin{array}{l}\text { Sub- } \\
\text { Scale }\end{array}$ & Dimension & $\begin{array}{l}\text { Grade } \\
\text { Level }\end{array}$ & $\mathbf{N}$ & $\mathbf{X}$ & SS & df & $\mathbf{F}$ & $\mathbf{p}$ & $\begin{array}{l}\text { Significant } \\
\text { Difference }\end{array}$ \\
\hline \multirow{16}{*}{$\begin{array}{l} \\
\\
\end{array}$} & \multirow{4}{*}{$\begin{array}{l}\text { Proposing } \\
\text { Questions and } \\
\text { Hypotheses }\end{array}$} & $1^{\mathrm{st}}$ & 77 & 4.03 & .57 & \multirow{4}{*}{3} & \multirow{4}{*}{1.820} & \multirow{4}{*}{.143} & \multirow{4}{*}{-} \\
\hline & & $2^{\text {nd }}$ & 101 & 4.18 & .48 & & & & \\
\hline & & $3^{\text {rd }}$ & 85 & 4.22 & .53 & & & & \\
\hline & & $4^{\text {th }}$ & 62 & 4.13 & .66 & & & & \\
\hline & \multirow{4}{*}{ Planning } & $1^{\text {st }}$ & 77 & 3.82 & .65 & \multirow{4}{*}{3} & \multirow{4}{*}{3.097} & \multirow{4}{*}{$.027 *$} & \multirow{4}{*}{$1-3$} \\
\hline & & $2^{\text {nd }}$ & 101 & 3.93 & .58 & & & & \\
\hline & & $3^{\text {rd }}$ & 85 & 4.08 & .50 & & & & \\
\hline & & $4^{\text {th }}$ & 62 & 4.05 & .68 & & & & \\
\hline & \multirow{4}{*}{$\begin{array}{l}\text { Experimenting } \\
\text { and Collecting } \\
\text { Data }\end{array}$} & $1^{\text {st }}$ & 77 & 4.04 & .59 & \multirow{4}{*}{3} & \multirow{4}{*}{1.621} & \multirow{4}{*}{.184} & \multirow{4}{*}{-} \\
\hline & & $2^{\text {nd }}$ & 101 & 4.04 & .65 & & & & \\
\hline & & $3^{\text {rd }}$ & 85 & 4.22 & .50 & & & & \\
\hline & & $4^{\text {th }}$ & 62 & 4.11 & .76 & & & & \\
\hline & \multirow{4}{*}{$\begin{array}{l}\text { Analyzing } \\
\text { Data, } \\
\text { Interpreting } \\
\text { and Reaching } \\
\text { Conclusions }\end{array}$} & $1^{\text {st }}$ & 77 & 3.93 & .61 & \multirow{4}{*}{3} & \multirow{4}{*}{4.649} & \multirow{4}{*}{$.003 *$} & \multirow{4}{*}{$2-3$} \\
\hline & & $2^{\text {nd }}$ & 101 & 3.87 & .56 & & & & \\
\hline & & $3^{\text {rd }}$ & 85 & 4.15 & .58 & & & & \\
\hline & & $4^{\text {th }}$ & 62 & 4.12 & .61 & & & & \\
\hline & \multirow{4}{*}{ Total } & $1^{\mathrm{st}}$ & 77 & 3.94 & .49 & \multirow{4}{*}{3} & & & \\
\hline & & $2^{\text {nd }}$ & 101 & 3.99 & .50 & & 210 & $025 \%$ & 12 \\
\hline & & $3^{\text {rd }}$ & 85 & 4.16 & .45 & & 3.142 & .025 & $1-3$ \\
\hline & & $4^{\text {th }}$ & 62 & 4.10 & .59 & & & & \\
\hline & & $1^{\text {st }}$ & 77 & 3.76 & .67 & & & & \\
\hline & Exnmosing & $2^{\text {nd }}$ & 101 & 3.77 & .68 & 2 & 2720 & $012 *$ & 1202 \\
\hline & Expressing & $3^{\text {rd }}$ & 85 & 4.04 & .59 & 3 & 3.720 & $.012^{*}$ & $1-3,2-3$ \\
\hline & & $4^{\text {th }}$ & 62 & 3.94 & .67 & & & & \\
\hline & & $1^{\text {st }}$ & 77 & 3.88 & .60 & & & & \\
\hline & Eyluoting & $2^{\text {nd }}$ & 101 & 3.84 & .59 & 3 & 5010 & $002 *$ & 020 \\
\hline 象 & Evaluatıng & $3^{\text {rd }}$ & 85 & 4.09 & .53 & 3 & 5.248 & $.002^{*}$ & $2-3,2-4$ \\
\hline . & & $4^{\text {th }}$ & 62 & 4.13 & .57 & & & & \\
\hline $\bar{\Xi}$ & & $1^{\mathrm{st}}$ & 77 & 4.04 & .62 & & & & \\
\hline $\bar{\Xi}$ & Interosting & $2^{\text {nd }}$ & 101 & 3.94 & .65 & 2 & 000 & 120 & \\
\hline ש & Interacting & $3^{\text {rd }}$ & 85 & 4.09 & .63 & 3 & .908 & .438 & - \\
\hline & & $4^{\text {th }}$ & 62 & 3.97 & .71 & & & & \\
\hline & & $1^{\mathrm{st}}$ & 77 & 4.00 & .64 & & & & \\
\hline & Noctiotin & $2^{\text {nd }}$ & 101 & 3.90 & .72 & 2 & 172 & $0 \cap 6 *$ & 20 \\
\hline & Negotiatıng & $3^{\text {rd }}$ & 85 & 4.21 & .48 & 3 & $4.1 / 3$ & $.000^{*}$ & $2-3$ \\
\hline & & $4^{\text {th }}$ & 62 & 4.14 & .66 & & & & \\
\hline & & $1^{\text {st }}$ & 77 & 3.91 & .49 & & & & \\
\hline & Totol & $2^{\text {nd }}$ & 101 & 3.86 & .54 & 2 & 4,420 & 004 & 23 \\
\hline & 1 otal & $3^{\text {rd }}$ & 85 & 4.11 & .47 & 3 & 4.439 & .004 & $2-3$ \\
\hline & & $4^{\text {th }}$ & 62 & 4.05 & .57 & & & & \\
\hline
\end{tabular}

\footnotetext{
$* \mathrm{p}<.05$
} 
As can be seen in Table 7 the grade level has significant effects on the scientific inquiry and communication skills of pre-service science teachers except for the sub dimensions of "Proposing Questions and Hypotheses", "Experimenting and Collecting Data" and "Interacting" $(p<.05)$. All significant differences are in favor of those pre-service science teachers, who were attending higher grades.

\section{Results Related to Fifth Sub-Problem}

Multiple regression analysis was conducted to determine the power of students' beliefs about the nature of science to predict their scientific inquiry and communication skills. For the multiple regression analysis to yield correct results, the correlations between independent variables $(\mathrm{r} \leq .80)$, CI index, tolerance, and VIF values were examined for multicollinearity. As a result of the analysis, it was seen that the correlation values between the variables were below .80. In addition, when VIF and tolerance values were examined, it was seen that the VIF value for each variable was less than 10 and the tolerance values for each variable were higher than .20. A critical value of tolerance $<.20$ is considered to be indicative of multicollinearity (Tatlidil \& Ortunç, 2011). It was observed that the CI value was less than 30. Considering the values obtained as a result of the analysis, it is seen that there is no multicollinearity problem between variables (Büyüköztürk, 2011). Based on these procedures, it was determined that the data are suitable for stepwise multiple regression analysis.

\section{Regression Analysis Results Related to Predicting Scientific Inquiry Skills of Students}

The results of the regression analysis made for the students' beliefs in the nature of science sub-dimension scores to predict the students' scientific inquiry skills total scores are given in Table 8.

Table 8. Regression analysis results related to predicting scientific inquiry skills of students

\begin{tabular}{|c|c|c|c|c|c|c|c|c|}
\hline Model & $\begin{array}{l}\text { Predictor } \\
\text { Vawioblas }\end{array}$ & B & $\mathbf{T}$ & $\mathbf{p}$ & $\mathbf{F}$ & $\mathbf{R}$ & $\mathbf{R}^{2}$ & $\begin{array}{l}\mathbf{R}^{2} \\
\mathrm{Cho}\end{array}$ \\
\hline 1 & Imagination and Creativity & .24 & 5.13 & .000 & 26.31 & .27 & .075 & .075 \\
\hline \multirow{2}{*}{2} & Imagination and Creativity & .19 & 3.88 & .000 & \multirow{2}{*}{17.92} & \multirow{2}{*}{.32} & \multirow{2}{*}{.100} & \multirow{2}{*}{.025} \\
\hline & Assumptions and Boundaries & .21 & 2.98 & .003 & & & & \\
\hline \multirow{3}{*}{3} & Imagination and Creativity & .17 & 3.45 & .001 & \multirow{3}{*}{14.15} & \multirow{3}{*}{.34} & \multirow{3}{*}{.120} & \multirow{3}{*}{.020} \\
\hline & Assumptions and Boundaries & .17 & 2.52 & .012 & & & & \\
\hline & Observation and Inference & .12 & 2.45 & .014 & & & & \\
\hline
\end{tabular}

$* \mathrm{p}<.05$

Three different regression models emerged as a result of the stepwise multiple regression analysis conducted to determine the power of the independent variable of beliefs about the nature of science to explain students' scientific inquiry skills.

According to Table 8, as a result of the stepwise multiple regression analysis, it was seen that the predictor that emerged at the first stage and contributed the most to the scientific inquiry skills was imagination and creativity. Imagination and creativity significantly explained $7 \%$ of the change in the total variance regarding scientific inquiry skills $\left(\mathrm{R}=.27, \mathrm{R}^{2}=.075, \mathrm{~F}(1\right.$, $323)=26.31, \mathrm{p}<.05)$. In the model of the second stage, it was shown that in addition to the imagination and creativity predictor, assumptions and boundaries of science together explained approximately $10 \%$ of the variance in scientific inquiry skills $\left(\mathrm{R}=.32, \mathrm{R}^{2}=.100, \mathrm{~F}\right.$ 
$(1,323)=17.92, \mathrm{p}<.05)$. In other words, the contribution of assumptions and boundaries of science to explaining the change in the variance in the scientific inquiry skills was approximately $3 \%$. At the third stage, the observation and inference was included in addition to imagination and creativity and assumptions and boundaries of science. The additional contribution of observation and inference to the variance explanation rate was $2 \%$, and three predictors explained $12 \%$ of the total variance regarding the scientific inquiry skills $(\mathrm{R}=.34$, $\left.\mathrm{R}^{2}=.120, \mathrm{~F}(1,323)=14.15, \mathrm{p}<.05\right)$. As a result of the study, it was revealed that the predictor variables of change of scientific knowledge, scientific method/methodology, socio-cultural effect and scientific theories and laws did not make a statistically significant contribution to explaining the change in the scientific inquiry skills.

\section{Regression Analysis Results Related to Predicting Communication Skills of Students}

The results of the regression analysis made for the students' beliefs in the nature of science sub-dimension scores to predict the students' communication skills total scores are given in Table 9.

Table 9. Regression analysis results related to predicting communication skills of students

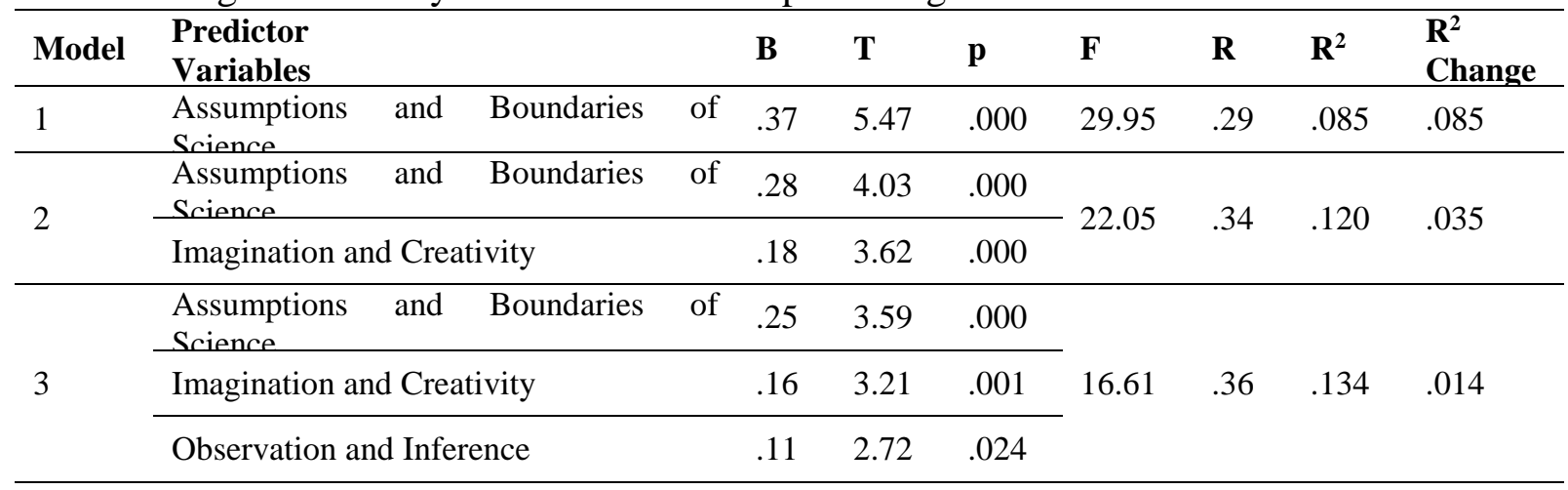

$* \mathrm{p}<.05$

Three different regression models emerged as a result of the stepwise multiple regression analysis conducted to determine the power of the independent variable of beliefs about the nature of science to explain students' communication skills.

According to Table 9, as a result of the stepwise multiple regression analysis, it was seen that the predictor that emerged at the first stage and contributed the most to the communication skills was assumptions and boundaries of science. Assumptions and boundaries of science significantly explained $8 \%$ of the change in the total variance regarding communication skills $\left(\mathrm{R}=.29, \mathrm{R}^{2}=.085, \mathrm{~F}(1,323)=29.95, \mathrm{p}<.05\right)$. In the model of the second stage, it was shown that in addition to the assumptions and boundaries of science predictor, imagination and creativity together explained approximately $10 \%$ of the variance in communication skills $\left(\mathrm{R}=.34, \mathrm{R}^{2}=.120, \mathrm{~F}(1,323)=22.05, \mathrm{p}<.05\right)$. In other words, the contribution of imagination and creativity to explaining the change in the variance in the communication skills was approximately $4 \%$. At the third stage, the observation and inference was included in addition to assumptions and boundaries of science and imagination and creativity. The additional contribution of observation and inference to the variance explanation rate was $1 \%$, and three predictors explained $13 \%$ of the total variance regarding the communication skills $(\mathrm{R}=.36$, $\left.\mathrm{R}^{2}=.134, \mathrm{~F}(1,323)=16.61, \mathrm{p}<.05\right)$. As a result of the study, it was revealed that the predictor 
variables of change of scientific knowledge, scientific method/methodology, socio-cultural effect and scientific theories and laws did not make a statistically significant contribution to explaining the change in the communication skills.

\section{Discussion and Conclusion}

Given that the pre-service science teachers' mean scores for the scale for the beliefs about the nature of science were higher than the median score $(M=3.00)$, it can be stated that the pre-service science teachers participated in the study have nearly "Acceptable" beliefs about the nature of science except for the dimension of "Scientific Method/Methodology". However, it also appears that their beliefs about scientific method/methodology are not contemporary beliefs. This may have influenced the prospective science teachers' tendency towards closed-ended experiments in their laboratory lessons during their university education. Thus, Kenar (2008) and Arı (2010) found that pre-service science teachers regarded the scientific method as a standard to be followed by scientists. When the related literature is examined, it is seen that there are studies supporting the current research results (Adedoyin \& Bello, 2017; Bayır, Çakıcı \& Ertaş Atalay, 2015; Korkmaz, 2018; Özcan, 2011; Saif, 2016; Ural, 2016). However, Tairab (2001) found that pre-service teachers' beliefs about the nature of science were well developed. In addition, Kremer et al. (2013) concluded that biology teachers had contemporary beliefs about the nature of science.

it was also found that the pre-service science teachers participated in the study had nearly higher levels of scientific inquiry and communication skills. Kremer et al. (2013) concluded that the level of pre-service biology teachers for scientific inquiry skills was high. Lederman, Lederman and Antink (2013) argued that in producing students with science literacy it is important to improve students' scientific inquiry skills. However, there are fewer studies dealing with the analysis of scientific inquiry skills. It may be a result of the fact that there is a lesser number of data collection tools specifically developed to measure scientific inquiry skills. When the literature on communication skills is examined, Saracaloğlu, Yenice and Karasakaloğlu (2009) stated that pre-service teachers, and similarly, Bulut (2004) and Çetinkaya (2011) concluded that both teachers and pre-service teachers had higher levels of communication skills. Therefore, it is safe to argue that all these findings are consistent with the present findings.

In the study it was also found that gender does not have any significant effects on the preservice science teachers' beliefs about the nature of science except for the dimension of "Scientific Theories and Laws". The gender-induced difference in the subdimension of "Scientific Theories and Laws" was in favor of female pre-service science teachers. Therefore, it can be said that female pre-service science teachers' beliefs about scientific laws and theories are more acceptable than males. Therefore, it can be said that female teacher candidates' beliefs about scientific laws and theories are more acceptable than those of male pre-service science teachers. However, in other dimensions the beliefs of the female and male pre-service teachers about the nature of science are similar. Scientific theories and laws may have caused a meaningful difference between female and male teachers' beliefs because they are two concepts that are mixed and cannot be defined clearly among individuals. There are studies showing that the beliefs about the nature of science do not show a significant difference according to gender (Adedoyin \& Bello, 2017; Güneş, 2010; Güzel, 2004; Oluwatayo, 2011; Taale, 2014). The reasons for the fact that gender does not have significant effects on the beliefs about the nature of science between the female and male pre-service teachers may be that females in Turkey have begun to be interested in science more as a result 
of endeavors targeting gender equality and that they have a scientific perspective and developed scientific literacy. Similarly, Abd-El-Khalick and Lederman (2000) found that gender did not lead to any significant difference in pre-service teachers' beliefs about the nature of science. In addition, Doğan and Abd-El-Khalick (2008) argued that although social, cultural and economic variables had a significant effect on students' beliefs about the nature of science; gender did not affect their beliefs. These findings are consistent with the present findings.

Gender was also found to not to have significant effects on the pre-service teachers' scientific inquiry and communication skills. It may be resulted from the fact that science education adopted an approach based on research and inquiry, which requires a good command of communication skills. Such an approach seems to improve the scientific inquiry and communication skills of both male and female student teachers. In an educational context communication plays a significant role. Therefore, all teachers regardless of gender should have communication skills (Tümkaya, 2011). Research also suggest that gender does not play a significant role in communication skills of teachers' and pre-service teachers' (Bulut, 2004; Çiftçi \& Taşkaya, 2010; Dilekmen, Başçı \& Bektaş, 2008; Pehlivan Baykara, 2005; Tümkaya, 2011; Yaman, 2020). However, there are other findings, suggesting that gender is a significant variable in communication skills and that females had much higher communication skills in contrast to males (Güven \& Akyüz, 2001; Özerbaş, Bulut \& Usta, 2007; Saracaloğlu, Özkütük \& Silkü, 2001; Şeker, 2000). It is difficult to generalize about gender variables because different results are obtained depending on this variable in the literature. However, there is no significant difference between teacher candidates according to gender, which is the expected result of researchers. As a matter of fact, communication skills should be one of the basic skills that must be found in effective teaching without the distinction between male and female student teachers.

Another finding of the study is that the grade level produced significant differences in the preservice science teachers' beliefs about the nature of science except for the dimension of "Scientific Method/Methodology". All significant differences are in favor of those pre-service science teachers, who were attending higher grades. Therefore, it seems that the pre-service science teachers attending higher grades had much more acceptable beliefs about the nature of science except for the dimension of "Scientific Method/Methodology" in contrast to those attending lower grades. In addition, it was found that the third grade pre-service science teachers' beliefs about the nature of science were higher than those of the fourth grade preservice science teachers. This may be due to the fact that prospective science teachers took the course of "the nature of science and the history of science" in the spring semester of the third grade. At the same time, most information about the nature of science may be forgotten by pre-service science teachers who are studying in the fourth grade. Özcan (2011) found that the fourth grader pre-service teachers had much more developed beliefs about the nature of science except for the dimensions of "Observation and Inference" and "Scientific Assumptions and Limits". Kenar (2008) concluded that grade levels of pre-service teachers led to significant differences in their beliefs about the nature of science. However, Gücüm (2000) found that grade levels of pre-service teachers did not cause significant differences in their beliefs about the nature of science.

It was also found that the grade level has significant effects on the scientific inquiry and communication skills of pre-service science teachers except for the subdimensions of "Proposing Questions and Hypotheses", "Experimenting and Collecting Data" and "Interacting" $(p<, 05)$. This difference was in favor of the third grader pre-service science 
teachers. Their scientific inquiry and communication skills are much higher than those of the other groups of pre-service science teachers. Kremer et al. (2013) concluded that increase in the grade level of the pre-service biology teachers resulted in improvement in their scientific inquiry skills. However, concerning communication skills Saracaloğlu, Yenice and Karasakaloğlu (2009) found that the first grader pre-service teachers had higher levels of communication skills. On the other hand, Tümkaya (2011) concluded that the fourth grader pre-service teachers had higher levels of communication skills. This finding is consistent with the findings of the studies by Çetinkaya (2011), Pehlivan Baykara (2005) and Y1lmaz, Üstün and Odac1 (2009), but not consistent with the findings of the studies by Bingöl and Demir (2011), Dilekmen, Başçı and Bektaş (2008) and Yaman (2020). It is an expected result that the scientific inquiry and communication skills of pre-service teachers improve based on their grade level. However, the fourth grader pre-service teachers were found to have lower scores in these dimensions. It may be that they focused on the national public personnel selection examination which is of highstakes and also on their teaching practices rather than scientific inquiry or communication skills. Such focus may decrease their self-efficiency. Moreover, this may also be due to the fact that the first grader pre-service teachers are less able to communicate with the students in the other classes because they have not been able to recognize the social environment due to their new start to the university, difficulty in adjusting, and not being able to make friends (Tümkaya, 2011).

According to the stepwise regression analysis results, the predictors that contribute the most to the scientific inquiry skills were imagination and creativity, assumptions and boundaries of science and observation and inference variables, respectively. It was determined that imagination and creativity and assumptions and boundaries of science together explained 10 $\%$ of the total variance in scientific inquiry skills. This value shows that $10 \%$ positive change in scientific inquiry skills can be achieved by improving students' beliefs of imagination and creativity and assumptions and boundaries of science. The observation and inference beliefs also have a positive effect on the variance in scientific inquiry skills, and it is revealed that imagination and creativity, assumptions and boundaries of science and observation and inference beliefs together explain approximately $12 \%$ of the total variance in scientific inquiry skills. Furthermore, it was determined in the study that the predictor variables of change of scientific knowledge, scientific method/methodology, socio-cultural effect and scientific theories and laws did not make a statistically significant contribution to the total variance. In the related literature, there is no study on pre-service teachers' beliefs about the nature of science to predict their scientific inquiry skills. However, there are studies that determine the relationships between pre-service teachers' beliefs about the nature of science and their scientific inquiry skills. Kremer et al. (2013) found that there is a positive significant correlation between pre-service teachers' skills about the nature of science and their inquiry skills in biology. Çetinkaya (2012) found that pre-service science teachers' beliefs about the nature of science and about the nature of scientific inquiry are significantly connected. It can be said that the mentioned study results support the current research results.

As a result of another result of the stepwise regression analysis, the predictors that contribute the most to the communication skills were found to be assumptions and boundaries of science, imagine and creativity and observation and inference variables, respectively. It was determined that assumptions and boundaries of science and imagination and creativity together explained $10 \%$ of the total variance in communication skills. This value shows that $10 \%$ positive change in communication skills can be achieved by improving students' beliefs of assumptions and boundaries of science and imagine and creativity. The observation and inference beliefs also have a positive effect on the variance in communication skills, and it is 
revealed that imagination and creativity, assumptions and boundaries of science and observation and inference beliefs together explain approximately $13 \%$ of the total variance in communication skills. Furthermore, it was determined in the study that the predictor variables of change of scientific knowledge, scientific method/methodology, socio-cultural effect and scientific theories and laws did not make a statistically significant contribution to the total variance. In the related literature, there is no study on pre-service teachers' beliefs about the nature of science to predict their communication skills. However, there are studies that determine the relationships between pre-service teachers' beliefs about the nature of science and their communication skills. Nielsen (2012) emphasized that the beliefs of the nature of science and communication skills are closely related each other. Therefore, the correlation between the beliefs of the nature of science and communication skills is an expected result. It can be said that the mentioned study results support the current research results.

In light of the results obtained from the research, the following suggestions are presented:

- The pre-service science teachers had nearly "Acceptable" beliefs about the nature of science, but their scientific method/methodology beliefs were traditional. The reasons for this situation can be determined by a qualitative study.

- In this study, it was concluded that imagination and creativity, assumptions and boundaries of science and observation and inference, explained approximately $12 \%$ of the variance in scientific inquiry skills and approximately $13 \%$ of the variance in communication skills. In this context, students' scientific inquiry and communication skills can be improved by organizing activities (Doğan, Çakıroğlu, Bilican ve Çavuş, 2009; Yenice \& Özden, 2019) related to the nature of science.

- It can be investigated in detail why pre-service science teachers' beliefs who are studying in the third grade are high in the nature of science, scientific inquiry and communication skills.

- This study, which is limited to pre-service science teachers, can be extended by the participation of pre-service teachers in different branches and by the inclusion of different variables (self-efficacy, entrepreneurship, metacognition and so on.) in the research.

\section{References}

Abd-El-Khalick, F., \& Lederman, N.G. (2000). Improving science teachers' conceptions of the nature of science: A critical review of the literature. International Journal of Science Education, 22, 665-701.

Adedoyin, A. O., \& Bello, G. (2017). Conceptions of the nature of science held by undergraduate pre-service biology teachers in south-west Nigeria. Malaysian Online Journal of Educational Sciences, 5(1), 1-9.

Arı, Ü. (2010). Investigation of the preservice science teachers' and preservice classroom teachers' wiews on nature of science. (Unpublised master's thesis). Firat University, Elazı $\breve{g}$.

Aydemir, S., Uğras, M., Cambay, O., \& Kılıç, A. (2017). Prospective pre-school teachers' views on the nature of science and scientific inquiry. UNIBULLETIN, 6(2), 74-87.

Ayyılmaz Çelik, H. (2019). Middle school in-service and prospective science teachers' views and knowledge about nature of science and scientific inquiry (Unpublished master's thesis). Aydın Adnan Menderes University, Aydın.

Baykara, H., Yakar, Z. \& Liu, S.Y. (2018). Preservice science teachers' views about scientific inquiry. European Journal of Education Studies, 4(10), 128-143. 
Bingöl, G. \& Demir, A. (2011). Communication skills of Amasya School of Health students. The Medical Journal of Goztepe Training and Research Hospital, 26(4), 152-159.

Bostan-Sarıoğlan, A. (2018). Assessment of preservice science teachers' views about scientific inquiry after training. Mehmet Akif Ersoy University Journal of Education Faculty, 48, 136-159.

Büyüköztürk, S. (2011). Manual of data analysis for social sciences. Ankara: Pegem A Publishing.

Bulut, B.N. (2004). Exploring primary class teachers' perceptions regarding communication skills according to certain variables. The Journal of Turkish Educational Sciences, 2(4), 443-452.

Çakmak, S. (2017). The views of science teachers and teacher candidates on the nature of science. (Unpublised master's thesis). Gazi University, Ankara.

Çepni, S., Ayvac1, H.Ş., \& Bacanak, A. (2006). A new perspective on science education: Science Technology-Society ( $3^{\text {rd }}$ Edition).Trabzon: Celepler Printing Press.

Çetinkaya Z. (2011). Identifying Turkish pre-service teachers' views related to communication skills. Kastamonu Education Journal, 19, 567-576.

Çetinkaya, G. (2012). Investigation of the relationship between preservice science teachers understandings of nature of science and their personal characteristics. (Unpublished master's thesis). Middle East Technical University, Ankara.

Chang, H.-P., Chen, C.-C., Guo, G.-J., Cheng, Y.-J., Lin, C.-Y., \& Jen, T.-H. (2011). The development of a competence scale for learning science: Inquiry and communication. International Journal of Science and Mathematics Education, 9(5), 1213-1233.

Çiftçi, S., \& Taşkaya, S.M. (2010). Relationship between self-efficacy and communication skills of classroom teacher candidates. $9^{\text {th }}$ National Primary Education Symposium (pp. 509-512), 20 -22 May 2010 Elazığ.

Colagrande, E. A., Martorano, S. A. A., \& Arroio, A. (2016). Assessment on how pre-service science teachers view the nature of science. Journal of Turkish Science Education, 13(4), 293-307.

Crawford, B. (2014). From inquiry to scientific practices in the science classroom. In N. Lederman \& S. Abell (Eds.), Handbook of research on science education, vol. II (pp. 515-544). New York: Taylor and Francis Group.

Creswell, J. W. (2008). Educational research: Planning, conducting, and evaluating quantitative and qualitative research. Upper Saddle River, NJ: Pearson Education.

Dilekmen, M., Başçı, Z., \& Bektaş, F. (2008). Communication skills of education faculty students. Journal of Graduate School of Social Sciences, 12(2), 223-231.

Doğan, N., \& Abd-El-Khalick, F. (2008). Turkish grade 10 students' and science teachers' conceptions of nature of science: A national study. Journal of Research in Science Teaching, 45(10), 1083-1112.

Doğan, N., Çakıroğlu, J., Bilican, K., \& Çavuş, S. (2009). Nature of science and teaching. Ankara: Pegem Academy.

Driver, R., Leach, J., Millar, R., \& Scott, P. (1996). Young people's images of science. Buckingham: Open University Press.

Erdoğan, R. (2004). Investigation of the preservice science teachers' views on nature of science. (Unpublished master's thesis). Middle East Technical University, Ankara.

George, D., \& Mallery, P. (2012). IBM SPSS statistics 19 step by step: A simple guide and reference $\left(12^{\text {th }}\right.$ Ed.). Boston: Pearson Education.

Gücüm, B. (2000). A research on science teaching students' understanding of the structure of scientific knowledge, IV. Science Education Congress, Hacettepe University, Ankara, pp. 147-150. 
Güneş, G. (2010). The analyze of the relation between astronomy knowledge with the nature of science and the astronomy self-efficacy belief of pre-service teachers. (Unpublised master's thesis). Çukurova University, Adana.

Güven, A., \& Akyüz, M.Y. (2001). Prospective teachers' views on communication and problem solving skills. Ege Journal of Education, 1(1), 13-22.

Güven, B. (2013). Communication concept and basic elements of communication process. In B. Güven (Eds.), Effective communication. (pp.1-20). Ankara: Pegem Academy.

Haefner, L. A. \& Zembal-Saul, C. (2004). Learning by doing? Prospective elementary teachers' developing understandings of scientific inquiry and science and learning. International Journal of Science Education, 26 (13), 1653-1674.

Hair, J., Black, W., Babin, B., \& Anderson, R. (2010). Multivariate data analysis ( ${ }^{\text {th }}$ Ed.). Upper Saddle River: Pearson Education Limited.

Kara, K. (2019). The effect of research inquiry-based learning approach on prospective chemistry teachers' learning and teaching approaches and their instructional design skills: An action research. (Unpublised master's thesis). Marmara University, İstanbul.

Kenar, Z. (2008). Prospective science teachers' views of the nature of science. (Unpublised master's thesis). Balıkesir University, Balıkesir.

Kesgin, D. (2019). Investigating of teacher candidates' views on the nature of science and Stem. (Unpublised master's thesis). Çanakkale Onsekiz Mart University, Çanakkale.

Klahr, D., \& Dunbar, K. (1988). Dual space search during scientific reasoning. Cognitive Science, 54, 1-48.

Korkmaz, D. (2018). Determination of the opinions of pre-service science teachers about the nature of science. (Unpublised master's thesis). Erciyes University, Kayseri.

Korkut, F. (2005). Communication skills training for adults. Hacettepe University Journal of Education Faculty, 28, 143-149.

Kremer, K., Specht, C., Urhahne, D., \& Mayer, J. (2014). Relationship in biology between nature of science and scientific inquiry. Journal of Biological Education (JBE), 48(1), $1-8$.

Lederman, N. G., Abd-El-Khalick, F., Bell, R., Schwartz, R. (2002). Views of nature of science questionnaire: Toward valid and meaningful assessment of learners' conceptions of nature of science. Journal of Research in Science Teaching, 39(6), 497-521.

Lederman, N.G. (1992). Students' and teachers' conceptions of the nature of science: A review of the research. Journal of Research in Science Teaching, 29(4), 331-359.

Lederman, N.G. (2007). Nature of science: Past, present, and future. In S.K. Abell, \& N.G. Lederman, (Ed.), Handbook of research in science education (pp 831-879). Mahwah, New Jersey: Lawrence Erlbaum Publishers.

Lederman, J. S. (2009). Teaching scientific inquiry: Exploration, directed, guided, and opened-ended levels. National geographic science: Best practices and research base, 820. Retrieved from http://bit. ly/2LMIrjR

Lederman, N.G., Lederman, J.S., \& Antink, A. (2013). Nature of science and scientific inquiry as contexts for the learning of science and achievement of scientific literacy. International Journal of Education in Mathematics, Science and Technology, 1(3), 138-147.

Lederman, J. S., Lederman, N. G., Bartos, S. A., Bartels, S. L., Meyer, A. A., \& Schwartz, R. S. (2014). Meaningful assessment of learners' understandings about scientific inquiry-The views about scientific inquiry (VASI) questionnaire. Journal of Research in Science Teaching, 51(1), 65-83. 
McComas, W.F., Clough, M.P., \& Almazroa, H. (1998). The role and character of the nature of science in science education'. Science \& Education, 7(6), 511-532.

Meyers, L.S, Gamst, G., \& Guarino, A.J. (2006). Applied multivariate research: Design and interpretation. London: SAGE Publications.

Milli, M. S., \& Yağc1, U. (2017). Research on communication skills of pre-service teachers. Abant Izzet Baysal University Journal of Education Faculty, 17(1), 286-298.

Ministry of National Education [MoNE] (2013). Science course (3. 4. 5. 6. 7. and 8.) Curriculum, Ankara.

Ministry of National Education [MoNE] (2018). Science course (3. 4. 5. 6. 7. and 8.) Curriculum, Ankara.

National Research Council [NRC]. (1996). National science education standards. Washington: National Academies Press.

National Research Council [NRC]. (2000). Inquiry and the national science education standards. Washington: National Academies Press.

Nielsen, K.H. (2012). Scientific communication and the nature of science. Science \& Education, 22(9), 2067-2086.

Ordu, S. (2019). Determining science teachers epistemological beliefs and exploring their influence on science teachers practices. (Unpublised master's thesis). Zonguldak Bülent Ecevit University, Zonguldak.

Özcan, I. (2011). Development of an instrument for the nature of science beliefs and identifying of the nature of science believing of pre-service science teachers. (Unpublised master's thesis). Marmara University, İstanbul.

Özcan, I., \& Turgut, H. (2014). Assessing preservice science teachers' nature of science understanding: a study of scale development. Sakarya University Journal of Education, 4(2), 38-56.

Özerbaş, M. A., Bulut, M., \& Usta, E. (2007). The investigation of pre service teachers' perceived communication skills level. Ahi Evran University Journal of Kırşehir Education Faculty, 8(1), 123-135.

Öztaş, F. (2019). Analysis of the scientific literacy levels of classroom teacher candidates and their views on the nature of science. (Unpublised master's thesis). Kahramanmaraş Sütçü İmam University, Kahramanmaraş.

Pedaste, M., Mäeots, M., Siiman, L. A., de Jong, T., van Riesen, S. A. N., Kamp, E. T., et al. (2015). Phases of inquiry-based learning: Definitions and the inquiry cycle. Educational Research Review, 14, 47-61.

Pehlivan Baykara, K. (2005). A study on perception of communication skills of preservice teachers. Elementary Education Online, 4(2), 17-23.

Roberts, D. A. (2008). Scientific literacy/science literacy. In S. K. Abell \& N. G. Lederman (Eds.), Handbook of research on science education (pp. 729-780). Mahwah, NJ: Lawrence Erlbaum Associates.

Roberts, R., \& Gott, R. (1999). Procedural understanding: Its place in the biology curriculum. School Science Review, 81, 19-25.

Şahin, A. (2007). The effects of types, quantity, and quality of questioning in improving students' understanding. (Unpublished doctoral dissertation). Texas A\&M University, Texas, USA.

Saif, A. D. A. (2016). The nature of science as viewed by science teachers in najran district, saudi arabia. Journal of Education and Practice, 7(12), 147-153.

Saracaloğlu, A. S., Özkütük, N., \& Silkü, A. (2001). Communication skills of university students. X. National Educational Sciences Congress, 7-9 June 2001.pp. 1754-1762, Bolu. 
Saracaloğlu, A.S., Yenice, N., \& Karasakaloğlu, N. (2009). The relationship between communication and problem solving skills and reading interest and habits of candidate teachers'. Van Yuzuncu Yll University Journal of Education, 6(2), 186-206.

Schwartz, R. S., \& Crawford, B. A. (2003). Critical elements for teaching about the nature of science in the context of authentic scientific inquiry: Practical guidelines for science teacher educators. Paper presented at the Association for the Education of Teachers of Science, St. Louis, MO.

Schwartz, R. S., Lederman, N. G., \& Crawford, B. A. (2004). Developing views of nature of science in an authentic context: An explicit approach to bridging the gap between nature of science and scientific inquiry. Science Education, 88(2), 610-645.

Shaakumeni, N.S., \& Csapo, B. (2019). Exploring the factorial validity of the beliefs about nature of science questionnaire. Science Education International, 30(1), 38-44.

Şeker, A. (2000). The Relation between the communicative skills of the teachers lecturing and the classroom atmosphere. (Unpublised master's thesis). Selçuk University, Konya.

Şenler, B. (2014). Turkish adaptation of the competence scale for learning science: validity and reliability study. Journal of Theory and Practice in Education, 10(2), 393-407.

Şenler, B. (2017). Examination of pre-service science teachers' science teaching self-efficacy beliefs and views about scientific inquiry. Journal of Education Theory and Practical Research, 3(2), 50-59.

Shaakumeni, S. N., \& Csapó, B. (2019). Exploring the factorial validity of the beliefs about nature of science questionnaire. Science Education International, 30(1), 38-44.

Stott, A., \& Hatting, A. (2020). Pre-service teachers' views about the nature of science and scientific inquiry: The South African case. South African Journal of Education, 40(1), $1-12$.

Taale, K. D. (2014). Gender and location influence on Ghanaian students' perceptions of energy and classroom learning. International Journal of Education and Practice, 2(3), 51-66.

Tatlidil, H., \& Ortunç, B. (2011). Pricing methods of credit default swaps and determination of financial indicators affecting pricing by regression and panel data analysis. Journal of Bankers, 77, 25-43.

The American Association for the Advancement of Science [AAAS] (1993). Science for all Americans: Project 2061. New York: Oxford University Press.

Tümkaya, S. (2011). Investigation of communication skills and attitude to teaching of the students of primary school teaching. Çukurova University Journal of Social Sciences Institute, 20(2), 49-62.

Ural, E. (2016). Comparison of pre-service science and pre-service primary school teachers' nature of science views. International Journal of Social Sciences and Education, 6(1), 98-108.

Wheaton, B., Muthen, B., Alwin, D., \& Summers, G. F. (1977), Assessing reliability and stability in panel models. Sociological Methodology, 8(1), 84- 136.

Yaman, C. (2020). The investigation of relationships towards prospective science teachers' information technology, communication skills, and self-efficacy perceptions towards science and technology. (Unpublised master's thesis). Aydın Adnan Menderes University, Aydin.

Yenice, N., \& Özden, B. (2019). Nature of science, development and teaching. In N. Yenice (Eds. 2nd edition), Activities used in teaching the nature of science. Ankara: An1 Publishing.

Yenice, N., Özden, B., \& Balc1, C. (2015). Examination of views about nature of science of preservice science and elementary school teachers'. Erzincan University Journal of Education Faculty, 17(1), 237-281. 
Yılmaz, M., Üstün, A., \& Odacı H. (2009). Examining the communication skills of pre-school teacher candidates according to various variables. The Black Sea Journal of Social Sciences, 1(1), 8-19. 